\title{
ASUPAN ZAT GIZI DAN TINGKAT PENDAPATAN KELUARGA TERHADAP KEJADIAN STUNTING PADA ANAK USIA 3-5 TAHUN
}

\author{
Grace K.L. Langi ${ }^{1}$, Vera T. Harikedua ${ }^{2}$, Rudolf B. Purba ${ }^{3}$, dan Janeke I. \\ Pelanginang ${ }^{4}$ \\ Jurusan Gizi Politeknik Kesehatan Kemenkes Manado \\ Email korespondens : kllge@yahoo.com
}

\begin{abstract}
One of the main challenges currently facing the health sector in Indonesia is chronic child malnutrition. Although many health developments and advances have been made in Indonesia over the past few years, the problem of stunting remains significant. The results of Basic Health Research showed that the prevalence of stunting in Indonesia in 2013 was 37.2\%. The results of the Nutrition Status Assessment (PSG), in the province of North Sulawesi, the prevalence of stunting according to the TB / U index in 2017 increased by 31.4\%. For Kotamobagu City the prevalence of stunting is $38.1 \%$. To determine the relationship of nutrient intake and the level of family income to the incidence of stunting in children aged 3-5 years in the work area of Upai City Health Center, Kotamobagu. This study used a cross sectional design with a sample size of 41 people. Measurement of variables was obtained from interviews using a questionnaire, 24-hour recall, and height measurements using microtoise. The results of this study indicate there is a relationship between iron intake with stunting, whereas energy intake has no relationship with stunting, protein intake has no relationship with stunting events, vitamin A intake has no relationship with stunting, and family income levels have no relationship with stunting. There is a relationship between iron intake and the incidence of stunting while the intake of energy, protein, vitamin $A$ and the level of family income have no relationship with the incidence of stunting.
\end{abstract}

\section{Keywords : Stunting Event, Nutrient Intake, Family Income Level}

\section{PENDAHULUAN}

Salah satu tantangan utama yang saat ini dihadapi sektor kesehatan di Indonesia adalah kekurangan gizi anak kronis. Meskipun banyak perkembangan dan kemajuan kesehatan telah dilakukan di Indonesia selama beberapa tahun terakhir, namun masalah stunting tetap signifikan. Pertumbuhan stunting menggambarkan suatu kegagalan pertumbuhan linear potensial yang seharusnya dapat dicapai, dan merupakan dampak dari buruknya kesehatan serta kondisi gizi seseorang (Fikawati dkk, 2017). Stunting berhubungan dengan menurunnya produktivitas ekonomi atau berkurangnya pendapatan pada usia produktif (Patimah, 2017). Tingkat pendapatan akan menentukan jenis dan ragam makanan yang akan dibeli. Kemampuan keluarga untuk membeli bahan makanan bergantung pada besar kecilnya pendapatan keluarga dan harga beli makanan (Adriani dan Wirjatmadi, 2014). Makanan yang dimakan ditentukan oleh kebiasaan makan seseorang, dan tingkat potensi tercapai sepenuhnya dipengaruhi oleh nutrisi yang dimakan. Kebiasaan makan dan nutrisi memiliki efek besar pada pola makan dan kemudian menentukan status gizi (Langi dkk, 2017).

Peggy (1993) mengatakan bahwa jumlah energi dan zat gizi yang dikonsumsi anak cenderung lebih tinggi pada anak yang berasal dari keluarga 
dengan status sosial ekonomi baik. Anak yang berasal dari keluarga dengan pendapatan $131 \%$ dari batas kemiskinan mengonsumsi $1427 \mathrm{kal} / \mathrm{hari}$ dan anak yang berasal dari keluarga dengan penghasilan 300\% mengonsumsi 1478 kkal/hari (Fikawati dkk, 2017). Hasil penelitian Illahi, (2017) menunjukkan bahwa proporsi balita stunting lebih banyak terdapat pada keluarga dengan pendapatan rendah yaitu sebesar $38,2 \%$, sedangkan pada keluarga dengan pendapatan tinggi terdapat $17,9 \%$ balita stunting.

Prevalensi stunting mulai meningkat pada usia 3 bulan, kemudian proses stunting melambat pada saat anak berusia sekitar 3 tahun. Terdapat perbedaan interpretasi kejadian stunting di antara kedua kelompok usia anak. Pada anak yang berusia di bawah 2-3 tahun, rendahnya kurva tinggi badan menurut usia (TB/U) kemungkinan menggambarkan proses gagal bertumbuh atau stunting yang masih sedang berlangsung/terjadi. Sementara pada anak yang berusia lebih tua (anak berusia lebih dari 3 tahun), hal tersebut menggambarkan keadaan dimana anak tersebut telah mengalami kegagalan pertumbuhan atau telah menjadi stunting (Fikawati dkk, 2017).

Secara global prevalensi stunting pada tahun 2016 adalah 22,9\% atau 154,8 juta anak di bawah usia 5 tahun mengalami stunting (WHO). Hasil Riset Kesehatan Dasar (Riskesdas 2013) menunjukkan bahwa prevalensi stunting di Indonesia tahun 2013 adalah 37,2\%, jika dibandingkan tahun 2010 (35,6\%) dan tahun 2007 (36,8\%) tidak menunjukkan penurunan /perbaikan yang signifikan (Balitbangkes, 2013). Berdasarkan hasil Penilaian Status Gizi (PSG), di provinsi Sulawesi Utara prevalensi stunting menurut indeks TB/U pada tahun 2017 meningkat yaitu 31,4\% jika dibandingkan pada tahun $2016(21,2 \%)$ dan pada tahun 2015 (22,2\%) (Direkgimas, 2017). Untuk Kota Kotamobagu prevalensi stunting yaitu 38,1\% (Riskesdas 2013) dan berdasarkan Puskesmas tahun 2018, jumlah anak balita di wilayah kerja Puskesmas Upai Kecamatan Kotamobagu Utara terdapat 262 orang anak usia 0-2 tahun, 162 orang anak usia 2-3 tahun, dan 255 orang anak usia 3-5 tahun. Tujuan penelitian mengetahui hubungan asupan zat gizi dan tingkat pendapatan keluarga terhadap kejadian stunting pada anak usia 3-5 tahun di wilayah kerja Puskesmas Upai Kecamatan Kotamobagu Utara.

\section{METODE}

Penelitian dilaksanakan pada tanggal 22 Januari - 08 Februari 2019 dengan mengambil tempat di Wilayah Kerja Puskesmas Upai Kota Kotamobagu. Jenis penelitian ini adalah deskriptif observasional analitik dengan menggunakan rancangan cross sectional, yaitu dimana pengukuran variabel bebas dan varibel terikat dilakukan pada waktu yang sama dalam satu kali pengukuran pada subjek penelitian. Variabel bebas : Asupan zat gizi dan tingkat pendapatan keluarga. Variabel terikat: Stunting. Cara pengambilan data dengan metode recall 24 jam selama dua hari.

\section{HASIL}

\section{Karakteristik Sampel}

Distribusi sampel menurut umur terbanyak pada umur 3 tahun yaitu 20 anak (48.8\%), umur 4 tahun yaitu 19 anak (46.3\%), sedangkan 5 tahun hanya 2 anak $(4.9 \%)$. Distribusi sampel menurut jenis kelamin terbanyak yaitu perempuan 
21 anak (51.2\%), laki-laki 20 anak (48.8\%). Distribusi kejadian stunting, yang memiliki kategori pendek sebanyak 30 anak $(73.2 \%)$ dan kategori sangat pendek 11 anak (26.8\%). Distribusi asupan energi, sebagian besar memiliki asupan energi $<80 \%$ sebanyak 30 anak $(73.2 \%)$ dan yang memiliki asupan energi $>80 \%$ hanya 11 anak $(26.8 \%)$.

Tabel 1. Distribusi Asupan Protein

\begin{tabular}{ccc}
\hline Asupan Protein & $\mathrm{n}$ & $\%$ \\
\hline Baik $>80 \%$ & 38 & 92,7 \\
Kurang $<80 \%$ & 3 & 7,3 \\
\hline Total & 41 & 100,0 \\
\hline
\end{tabular}

Distribusi asupan protein sebagian besar memiliki asupan protein $>80 \%$ sebanyak 38 anak $(92.7 \%)$ dan yang memiliki asupan protein $<80 \%$ hanya 3 anak (7.3\%). Distribusi asupan zat besi sebagian besar memiliki asupan zat besi $<80 \%$ yaitu 23 anak (56.1\%) dan yang memiliki asupan zat besi $>80 \%$ hanya 18 anak (43.9\%). Distribusi asupan vitamin A sebagian besar memiliki asupan vitamin A > $80 \%$ sebanyak 23 anak (56.1\%) dan yang memiliki asupan vitamin $A<80 \%$ hanya 18 anak (43.9\%). Distribusi tingkat pendapatan keluarga, sebagian besar memiliki pendapatan < UMP Rp 2.824.286 sebanyak 35 keluarga $(85.4 \%)$ dan yang memiliki pendapatan > UMP Rp 2.824.286 hanya 6 keluarga $(14.6 \%)$.

\section{Hasil Analisis Bivariat}

Tabel 2. Hubungan Asupan dengan Kejadian Stunting

\begin{tabular}{|c|c|c|c|c|}
\hline \multirow{2}{*}{ Asupan Energi } & \multicolumn{2}{|c|}{ Stunting } & \multirow{2}{*}{ Total } & \multirow{2}{*}{$p$} \\
\hline & Pendek & Sangat Pendek & & \\
\hline Baik > 80\% & 10 & 1 & 11 & \multirow{3}{*}{0,128} \\
\hline Kurang $<80 \%$ & 19 & 11 & 30 & \\
\hline Total & 29 & 12 & 41 & \\
\hline \multirow{2}{*}{ Asupan Protein } & \multicolumn{2}{|c|}{ Stunting } & \multirow{2}{*}{ Total } & \multirow{2}{*}{$p$} \\
\hline & Pendek & Sangat Pendek & & \\
\hline Baik > 80\% & 28 & 10 & 38 & 0,20 \\
\hline Kurang $<80 \%$ & 1 & 2 & 3 & 0 \\
\hline Total & 29 & 12 & 41 & \\
\hline \multirow{2}{*}{ Asupan Zat Besi } & \multicolumn{2}{|c|}{ Stunting } & \multirow{2}{*}{ Total } & \multirow{2}{*}{$P$} \\
\hline & Pendek & Sangat Pendek & & \\
\hline Baik $>80 \%$ & 16 & 2 & 18 & \\
\hline $\begin{array}{l}\text { Kurang < } \\
80 \%\end{array}$ & 13 & 10 & 23 & 0,024 \\
\hline Total & 29 & 12 & 41 & \\
\hline
\end{tabular}




\begin{tabular}{|c|c|c|c|c|}
\hline \multirow{2}{*}{$\begin{array}{c}\text { Asupan Vitamin } \\
\text { A }\end{array}$} & \multicolumn{2}{|c|}{ Stunting } & \multirow{2}{*}{ Total } & \multirow{2}{*}{$p$} \\
\hline & Pendek & Sangat Pendek & & \\
\hline Baik > 80\% & 18 & 5 & 24 & 0,23 \\
\hline Kurang $<80 \%$ & 11 & 7 & 17 & 1 \\
\hline Total & 29 & 12 & 41 & \\
\hline \multirow[b]{2}{*}{$\begin{array}{c}\text { Tingkat Pendapatan } \\
\text { Keluarga }\end{array}$} & \multicolumn{2}{|r|}{ Stunting } & \multirow[b]{2}{*}{ Total } & \multirow[b]{2}{*}{$p$} \\
\hline & $\begin{array}{l}\mathrm{n} \text { Pende } \\
\mathrm{k}\end{array}$ & $\begin{array}{l}\text { Sangat } \\
\text { Pendek }\end{array}$ & & \\
\hline \multirow{2}{*}{$\begin{array}{l}\text { > UMP Rp. } \\
2.824 .286 \\
<\text { UMP Rp. } \\
2.824 .286\end{array}$} & 4 & 2 & 6 & \multirow[t]{2}{*}{$\begin{array}{c}1,00 \\
0\end{array}$} \\
\hline & 25 & 10 & 35 & \\
\hline Total & 29 & 12 & 41 & \\
\hline
\end{tabular}

Hasil analisis untuk mengetahui hubungan antara asupan energi dengan kejadian stunting diperoleh hasil $p$ value $0,128(p=0,05)$, tidak terdapat hubungan yang signifikan antara asupan energi dengan kejadian stunting. Sedangkan hubungan antara asupan protein dengan kejadian stunting diperoleh hasil $p$ value $0,200(p=0,05)$, tidak terdapat hubungan yang signifikan antara asupan protein dengan kejadian stunting. Selanjutnya hubungan antara asupan zat besi dengan kejadian stunting diperoleh hasil $p$ value $0,024(p=0,05)$ yang berarti terdapat hubungan yang signifikan antara asupan zat besi dengan kejadian stunting. Demikian pula hubungan antara asupan vitamin A dengan kejadian stunting diperoleh hasil $p$ value $0,231(p=0,05)$ yang berarti tidak terdapat hubungan yang signifikan antara asupan vitamin A dengan kejadian stunting. Akan tetapi, hubungan antara tingkat pendapatan keluarga dengan kejadian stunting diperoleh hasil $p$ value $1,000(p=0,05)$, tidak terdapat hubungan yang signifikan antara tingkat pendapatan keluarga dengan kejadian stunting.

\section{PEMBAHASAN}

Hasil analisis dari uji chi square menunjukkan bahwa tidak terdapat hubungan yang signifikan antara asupan energi dengan kejadian stunting dengan nilai $p$ value $0,128>0,05$. Hasil ini sejalan dengan penelitian Astutik dkk, (2018) hasil uji menggunakan chi square menunjukkan bahwa tidak ada hubungan antara tingkat asupan energi dengan kejadian stunting pada balita $(p=0,620)$. Berbeda dengan penelitian Ayuningtias dkk, (2018) yang menunjukkan bahwa ada hubungan yang signifikan antara asupan energi dengan kejadian stunting pada balita dengan nilai $p=0,001 \quad(p<0,05)$. Kurangnya asupan energi atau ketidakcukupan konsumsi zat-zat gizi penting yang diperlukan tubuh biasanya akan menyebabkan menurunnya aktivitas yang dilakukan. Energi berfungsi sebagai zat tenaga untuk metabolisme, pertumbuhan, pengaturan suhu tubuh, dan kegiatan fisik (Fikawati dkk, 2017).

Hasil analisis dari uji chi square menunjukkan bahwa tidak terdapat hubungan yang signifikan antara asupan protein dengan kejadian stunting dengan nilai $p$ value $0,200>0,05$. Hasil ini sejalan dengan penelitian Sumardilah \& Rahmadi (2019) berdasarkan uji chi-square $p=0,28(p=0,05)$ menunjukkan bahwa secara statistik tidak ada hubungan yang bermakna antara asupan protein dengan kejadian stunting. Hal ini disebabkan karena kejadian stunting merupakan 
peristiwa yang terjadi dalam periode waktu lama, sehingga tingkat konsumsi protein yang terjadi sekarang tidak menjadi salah satu penyebab kejadian stunting.

Kebutuhan protein anak berguna untuk pemeliharaan jaringan, perubahan komposisi tubuh, dan untuk sintesis jaringan baru. Sebaiknya anak memperoleh $13-15 \%$ protein yang dibutuhkan dari total asupan makan per harinya. Protein hewani sangat dibutuhkan untuk menyokong pertumbuhan dan perkembangan anak karena zat gizi yang terkandung dalam protein hewani sebagian besar adalah zat gizi yang mendukung pertumbuhan otak anak dan berperan dalam pertumbuhan. Walaupun ketersediaan biologis protein dari sumber nabati tidak begitu tinggi karena komposisi asam amino esensialnya tidak lengkap dibandingkan dengan protein yang berasal dari produk hewani, namun protein nabati tetap mempunyai peran dalam menyediakan protein (Fikawati dkk, 2017).

Hasil analisis dari uji chi square menunjukkan bahwa terdapat hubungan yang signifikan antara asupan zat besi dengan kejadian stunting $p$ value 0,024 $<0,05$. Hasil ini sejalan dengan penelitian Dewi \& Nindya (2017) yang menunjukkan nilai $p=0,011<0,05$ yang memiliki arti terdapat hubungan yang signifikan antara tingkat kecukupan zat besi dengan kejadian stunting pada balita.

Kekurangan zat besi dapat disebabkan beberapa hal, seperti asupan makanan yang rendah zat besi atau mungkin zat besi dalam makanan terdapat dalam bentuk yang sulit untuk diserap. Zat besi dalam jumlah yang sangat tinggi bersifat racun, sehingga tubuh memiliki sistem untuk mempertahankan zat besi dalam keadaan normal. Sela pada usus halus membentuk protein pengikat zat besi yang disebut ferritin, yaitu bentuk simpanan zat besi dalam darah dan jaringan. Apabila simpanan dalam jumlah sedikit, maka ferritin akan dibentuk dalam jumlah sedikit pula. Anak pada masa perkembangan paling pesat memiliki rekomendasi terbesar untuk mengkonsumsi zat besi karena volume darah meningkat lebih cepat (Fikawati, dkk 2013).

Hasil analisis dari uji chi square menunjukkan bahwa tidak terdapat hubungan yang signifikan antara asupan vitamin A dengan kejadian stunting $p$ value 0,231 >0,05. Hasil penelitian ini searah dengan penelitian Astutik dkk, (2018) berdasarkan uji chi-square di dapatkan $p$-value $=0,801$ ( $p>0,05)$, yang berarti tidak ada hubungan antara asupan vitamin A dengan kejadian stunting pada balita.

Vitamin A berperan dalam pertumbuhan dan perkembangan. Vitamin A dibutuhkan untuk perkembangan tulang dan sel epitel yang membentuk email dalam pertumbuhan gigi. Vitamin A juga berperan dalam meningkatkan nafsu makan. Defisiensi vitamin A dapat menyebabkan berkurangnya nafsu makan. Pada kekurangan vitamin $A$, pertumbuhan tulang terhambat dalam bentuk tulang tidak normal. Pada anak yang kekurangan vitamin A, terjadi kegagalan dalam pertumbuhan (Adriana \& Wirjatmadi 2014).

Hasil analisis dari uji chi square menunjukkan bahwa tidak terdapat hubungan yang signifikan antara tingkat pendapatan keluarga dengan kejadian stunting $p$ value $1,000>0,05$. Hasil ini searah dengan penelitian Syabandini, dkk (2018) berdasarkan hasil uji chi-square didapatkan $p$-value $=1$ yang dapat disimpulkan bahwa tidak ada hubungan antara pendapatan dengan kejadian stunting. Hal ini disebabkan karena jika keluarga tersebut berpendapatan rendah, pangan hewani mampu dijangkau dengan cara di beli atau di cari sehingga kebutuhan pangan keluarga yang berpendapatan tinggi maupun rendah dapat menjangkau pangan tersebut, sehingga pendapatan bukan merupakan faktor risiko kejadian stunting. Namun perlu diketahui, bahwa pengeluaran uang yang lebih banyak untuk pangan tidak menjamin lebih beragamnya konsumsi pangan. 
Kadang perubahan utama yang terjadi dalam kebiasaan makan yaitu pangan yang dimakan lebih mahal. Kemampuan keluarga untuk membeli bahan makanan, antara lain bergantung pada besar kecilnya pendapatan keluarga dan harga bahan makanan. Pola pengeluaran untuk membeli bahan pangan antara keluarga dengan pendapatan tinggi dan keluarga dengan pendapatan rendah berbeda (Adriani \& Wirjatmadi 2014).

\section{KESIMPULAN}

Kejadian stunting dengan kategori pendek berjumlah 29 anak $(70.7 \%)$ dan kategori sangat pendek berjumlah 12 anak (29.3\%). Asupan zat gizi yaitu asupan energi sebagian besar memiliki asupan energi kurang $<80 \%(73.2 \%)$ sebanyak 30 anak, dan tidak terdapat hubungan antara asupan energi dengan kejadian stunting. Untuk asupan protein sebagian besar memiliki asupan protein baik $>80 \%$ $(92.7 \%)$ sebanyak 38 anak, dan tidak terdapat hubungan antara asupan protein dengan kejadian stunting. Untuk asupan zat besi sebagian besar memiliki asupan zat besi kurang $<80 \%(56.1 \%)$ sebanyak 23 anak, dan terdapat hubungan antara asupan zat besi dengan kejadian stunting. Untuk asupan vitamin A sebagian besar memiliki asupan vitamin A baik $>80 \%(56,1 \%)$ sebanyak 23 anak, dan tidak terdapat hubungan antara asupan vitamin A dengan kejadian stunting. Tingkat pendapatan keluarga sebagian besar memiliki pendapatan < UMP Rp 2.824.286 (85.4\%) berjumlah 35 keluarga dan tidak ada hubungan antara tingkat pendapatan keluarga dengan kejadian stunting. Saran bagi Ibu Balita, diharapkan lebih aktif untuk mencari informasi yang berkaitan dengan asupan gizi agar bisa mencegah terjadinya kejadian stunting pada anak. .

\section{DAFTAR PUSTAKA}

Adriani, M. dan Wirjatmadi, B. (2014). Gizi dan Kesehatan pada Balita. Kencana, Jakarta.

Angka Kecukupan Gizi (AKG). 2013

Astutik, M. Rahfiludin, Z. \& Aruben, R. (2018). Faktor Risiko Kejadian Stunting pada Anak Balita Usia 24-59 Bulan. Jurnal Kesehatan Masyarakat. 6 (1:2356-3346).

Ayuningtyas. Simbolon, D. \& Rizal, A. (2018). Asupan Zat Gizi Makro dan Mikro terhadap Kejadian Stunting pada Balita. Jurnal Kesehatan. 9 (3:443-449).

Balitbangkes, (2013). Riset Kesehatan Dasar Indonesia, Jakarta

Balitbangkes, (2013). Riset Kesehatan Dasar Provinsi Sulawesi Utara, Jakarta

Damayanti, R. A. Muniroh, L. \& Farapti (2016). Perbedaan Tingkat Kecukupan Zat Gizi dan Riwayat Pemberian ASI Eksklusif pada Stunting dan Non Stunting. Media Gizi Indonesia. 11 (1:61-69).

Data Stunting Kota Kotamobagu Berdasarkan Puskesmas. (2018).

Dewi, I. A. K. dan Adhi, K. T. (2016). Pengaruh Konsumsi Protein dan Seng serta Riwayat Penyakit Infeksi Terhadap Kejadian Stunting pada Anak Balita Umur 24-59 Bulan di Wilayah Kerja Puskesmas Nusa Penida III. Arc. Com Health. 3 (1:36-46).

Dewi, E. K. dan Nindya, T. S. (2017). Hubungan Tingkat Kecukupan Zat Besi dan Seng dengan Kejadian Stunting pada Balita 6-23 Bulan. Departemen Gizi Kesehatan, Fakultas Kesehatan Masyarakat-Universitas Airlangga.

Direkgimas, (2017). Buku Saku Pemantauan Status Gizi (PSG), Jakarta.

Fikawati, S. Syafiq, A. \& Veratamala, A. (2017). Gizi Anak dan Remaja. Rajagrafindo Persada, Depok. 
Fatimah, N. S. H dan Wirjatmadi, R. B. (2018). Tingkat Kecukupan Vitamin A. Seng dan Zat Besi serta Frekuensi Infeksi pada Balita Stunting dan Non Stunting. Media Gizi Indonesia. 13(2:168-175).

Feybe M. (2017). Beritasatu TV. http://www.beritasatu.com/nasional/461547/umpsulawesi-utara-tahun-2018-rp-28-juta. di akses tanggal 2 November 2017.

Hanum, F. Khomsan, A. \& Heryatno, Y. (2014). Hubungan Asupan Gizi dan Tinggi Badan Ibu dengan Status Gizi Anak Balita. Jurnal Gizi dan Pangan. 9 (1:16).

Hasdianah, Siyoto, S. dan Peristyowati, Y. (2014). Gizi Pemanfaatan Gizi, Diet, dan Obesitas. Nuha Medika,Yogyakarta.

Illahi, R. K. (2017). Hubungan Pendapatan Keluarga, Berat Lahir, dan Panjang Lahir dengan Kejadian Stunting Balita 24-59 Bulan di Bangkalan. Jurnal Manajemen Kesehatan Yayasan RS. Dr. Soetomo. 3 (1:1-14).

Infodatin, Situasi Balita Pendek. (2016). Pusat Data dan Informasi Kementerian Kesehatan RI.

Kusharto, C. M. dan Supariasa, I. D. N. (2014). Survei Konsumsi Gizi. Graha IImu, Yogyakarta.

Langi, G. K .L. Legi, N. N. \& Yunus, R. (2017). Different Eating Habits Tinutuan As Local Food On Rulal Area and Urban Area In North Sulawesi Province. Issue 1, 1.

Nabuasa, C. D, Juffrie, M. dan Huriyati, E. (2013). Riwayat Pola Asuh, Pola Makan, Asupan Zat Gizi Berhubungan dengan Stunting pada Anak 24-59 Bulan di Biboki Utara, Timor Tengah Utara, Nusa Tenggara Timur. Jurnal Gizi dan Dietetik Indonesia. 1 (3:151-163).

Nasir, ABD. Muhith, A. dan Ideputri, M. E (2011). Buku Ajar Metodologi Penelitian Kesehatan. Nuha Medika, Yogyakarta.

Ni'mah, K. dan Nadhiroh, S. R. (2015). Faktor yang Berhubungan dengan Kejadian Stunting pada Balita. Media Gizi Indonesia. 10 (1:13-19).

Maulidah, W.B. dan Rohmawati, N. (2019). Faktor yang Berhubungan dengan Kejadian Stunting pada Balita di Desa Panduman Kecamatan Jelbuk Kabupaten Jember. IImu Gizi Indonesia. 2 (2:89-100).

Millennium Challenge Account, Stunting dan Masa Depan Indonesia (2014).

Oktarina, Z. \& Sudiarti, T. (2013). Faktor Risiko Stunting pada Balita (24-59 Bulan) di Sumatera. 8 (3:175-180).

Patimah, S. (2017). Gizi Remaja Putri Plus 1000 Hari Pertama Kehidupan. Refika Aditama, Bandung.

Sabyandini, I. P. Pradigdo, S. F. Suyatno. \& Pangestuti, D. R. (2018). Faktor Risiko Kejadian Stunting pada Anak Usia 6-24 Bulan di Daerah Nelayan. Jurnal Kesehatan Masyarakat. 6 (1:235-334).

Siswanto, Susila, \& Suyanto. (2014). Metodologi Penelitian Kesehatan dan Kedokteran. Bursa IImu, Yogyakarta.

Sumardilah, D.S. dan Rahmadi, A. (2019). Risiko Stunting Anak Baduta (7-24 bulan). Jurnal Kesehatan. 10 (1:93-104).

Supariasa, I. D. N. Bakri, B. \& Fajar, I. (2013). Penilaian Status Gizi, Penerbit Buku Kedokteran EGC, Jakarta.

Wahyuningsih, R. (2013). Penatalaksanaan Diet Pada Pasien. Graha Ilmu. Yogyakarta.

World Health Organization. (2018). Reducing Stunting In Children. 